DOI: 10.20472/IAC.2017.031.047

\author{
PADMAKSHI SHARMA \\ PANDIT DEENDAYAL PETROLEUM UNIVERSITY, India
}

\title{
TO STUDY THE CONSUMERS BUYING BEHAVIOR TOWARDS CLOTHING RETAIL BRANDS IN AHMEDABAD CITY.
}

\begin{abstract}
:
Clothing sector is one of the oldest industries in India. India is witnessing change in lifestyle of large section of population. Clothing also forms to be a basic need of living. To understand the consumer behavior concerning to leading clothing brands.

Consumers give importance to brands and relate their prestige with different brands. They see brands in different perspectives and expect better quality of brands. For the consumers to identify their needs to understand how they behave what influences them to buy particular clothing brand what process they follow while selecting a product or service. Consumer attributes (like brand consciousness, social class $\&$ other factors personal characteristics) were explored in relation to the purchase behavior of the youth. Also this paper helps to understand that what the reasons consumers make for purchasing the product. Also study how factors influence consumer purchases. The purpose of the research is to investigate the youth in the city of Ahmedabad to understand if any factors affect their buying behavior for clothes.
\end{abstract}

\section{Keywords:}

Consumer Perception, Consumer Buying behavior, Clothing retail brand 